Article

\title{
Post-Harvest Stand Dynamics over Five Years in Selectively Logged Production Forests in Bago, Myanmar
}

\author{
Tual Cin Khai ${ }^{1}$, Nobuya Mizoue ${ }^{2, *(\mathbb{D})}$ and Tetsuji Ota ${ }^{2,3}$ \\ 1 Graduate School of Bioresource and Bioenvironmental Sciences, Kyushu University, 744 Motooka, Fukuoka \\ 819-0395, Japan; tualcinkhai@gmail.com \\ 2 Faculty of Agriculture, Kyushu University, 744 Motooka, Fukuoka 819-0395, Japan; \\ ota.tetsuji.887@m.kyushu-u.ac.jp \\ 3 Institute of Decision Science for a Sustainable Society, Kyushu University, 744 Motooka, Fukuoka 819-0395, \\ Japan \\ * Correspondence: mizoue@agr.kyushu-u.ac.jp; Tel.: +81-92-802-4641
}

Received: 3 February 2020; Accepted: 6 February 2020; Published: 10 February 2020

check for updates

\begin{abstract}
Understanding the stand dynamics of tropical production forests is essential for determining the sustainability of a polycyclic selective logging system, but limited related studies have addressed the impacts of illegal logging over time. Myanmar faces the extensive degradation of traditional production forests with a 160-year logging history, but the cause of this degradation and how to balance legal and/or illegal disturbances with recovery in over-logged forests remain unclear. The present study investigated stand structural changes over 5 years after official legal logging operations using two 1-ha $(100 \times 100 \mathrm{~m})$ sample plots. For 5 years after logging, the volume of trees with a diameter at breast height $(\mathrm{DBH}) \geq 20 \mathrm{~cm}$ decreased by $46.0 \%$ from 121 to $65.1 \mathrm{~m}^{3} \mathrm{ha}^{-1}$, with a significant loss of the first- and second-grade species group (Tectona grandis Linn. $\mathrm{f}$. and Xylia xylocarpa (Roxb.) Taub.) from 48.3 to $6.8 \mathrm{~m}^{3} \mathrm{ha}^{-1}$. The total tree loss owing to official logging operations, mainly targeting the second- and fourth-grade species group, was $29.3 \mathrm{~m}^{3} \mathrm{ha}^{-1}$. A similar level of total tree loss $\left(28.0 \mathrm{~m}^{3} \mathrm{ha}^{-1}\right)$ was attributed to illegal logging that targeted the first- and second-grade species group. The mean annual recruitment rate of 3.1\% was larger than the reported values for tropical forests, but there were no and only 1.5 trees ha $^{-1}$ recruitments s for T. grandis and X. xylocarpa, respectively. The mean annual mortality rate of $2.5 \%$ was within the values reported in the related literature, and the volume loss from the mortality was relatively similar to the gain from the increment of living trees for all species groups. We concluded that the effects of illegal disturbances for 5 years post-harvest were equivalent to those of legal disturbances and larger than those of natural change, and are a major cause of the substantial reduction in stocking levels, especially for commercial species.
\end{abstract}

Keywords: illegal logging; mortality; recruitment; tropical mixed deciduous forest; teak

\section{Introduction}

Tropical forests, representing $\sim 44 \%$ of global forests (1770 million ha in area) [1], represent a widely recognized and important ecosystem for maintaining carbon stocks and biodiversity, and they play key roles in the provision of nearly $15 \%$ of global timber $[2,3]$. Consequently, attention has focused on the impacts of selective harvesting, which is a common operation in tropical timber production [4], and the re-establishment of disturbed forests [5]. Sustainable forest management for timber production demands that forest functions are maintained and that the growing stock recovers during the cutting cycle to allow the continuous provision of ecosystem services and sustainable yields 
of target species [6]. Therefore, it is very important to obtain reliable information on stand dynamics and species compositional shifts after selective logging $[7,8]$.

In an attempt to assess the stand dynamics of disturbed tropical forests, comparative information on the changes in size structure, species composition, and demographic processes, such as growth, mortality, and recruitment, has been obtained [9-13]. These studies used data between two censuses at different periods or between disturbed and undisturbed control plots. Investigating the dynamics in post-harvest forests is not simple because the forest structure is the result of natural processes, such as tree growth, mortality, and recruitment; natural disturbances, such as forest fires and wind damage; and human disturbances, such as illegal logging. However, only a few studies $[14,15]$ have considered illegal logging, which may have considerably great effects on stand dynamics in tropical production forests.

Myanmar is a tropical timber-producing country in Southeast Asia which uses the traditional Myanmar selection system that evolved in the 1860s. The Myanmar selection system originally focused on the sustainable production of teak (Tectona grandis Linn. f.), and its theories and practices have been subsequently applied to other commercial species [16]. This system attempts to ensure sustained yields of commercial species using a 30-year cutting cycle, and the harvestable size is regulated using a minimum diameter cutting limit (MDCL), which is 58 to $78 \mathrm{~cm}$, depending on the species. The annual allowable cut $(\mathrm{AAC})$ is calculated based on the number of future harvestable trees that will reach the MDCL within the next 30 years, and an assumed diameter growth rate $\left(0.32 \mathrm{~cm}_{\text {year }}{ }^{-1}\right)$ is adopted to predict the harvestable trees. Until recently, the forestry sector was responsible for approximately one-third of the country's total export earnings and was a major source of foreign exchange. Owing to its implementation for hundreds of years of selective logging in tropical production forests [17], the Myanmar selection system can be considered a sustainable practice and suitable for maintaining multi-species, natural teak-bearing forests [18]. However, studies using remote sensing have revealed that forest degradation, defined as the reduction of canopy cover, has occurred in selectively logged forests in Myanmar during recent decades [19,20]. Win et al. (2018) [21] used large-scale forest inventory data from the systematic sampling of $4 \mathrm{~km} \times 4 \mathrm{~km}$ grids to reveal widespread forest degradation in the production forests of Myanmar, in which there were very few large harvestable trees of commercial species. In addition, Win et al. (2018) [14] investigated legally and illegally cut stumps to reveal that the amount of illegally cut trees was much greater than legally cut trees and that illegal cutting increased after legal cutting. Under such negative forest conditions, the forest policy in 2016 eventually introduced a country-wide logging ban policy for 2016-17 and a 10-year fallow period in Bago Yoma, which is the main extraction area of Myanmar.

While the long-standing practices of Myanmar have been questioned since production forests were threatened by forest degradation, Khai et al. (2016) [22] reported that the Myanmar operations (felling, skidding, and road construction) caused relatively limited residual tree damage and ground disturbance compared with tropical forest logging operations in other countries. In light of such research findings, illegal logging may be a main reason for forest degradation. However, the extent of illegal logging's impact on stand dynamics over time compared with the other components, such as natural mortality, and the recruitment and growth of living trees, is unknown. Studies on the structures, growth rates, and yields of natural teak forests in Myanmar started with the commencement of working-plan operations in as early as the late 19th century [23]. The diameter growth rate $\left(0.32 \mathrm{~cm}\right.$ year $\left.{ }^{-1}\right)$ of teak, based on tree ring counting at the time, was used for the AAC calculation. However, it is questionable whether the growth rates of production forests that have been subject to selective logging for one and a half centuries remain constant. Although data on growth rates of commercial plantation trees are common in Myanmar forestry, updated and reliable data on the growth and yields of natural production forests are still lacking.

The objective of this study is to evaluate impacts of illegal logging on stand dynamics in a traditional production forest in Myanmar. For this, in this paper, we investigate changes in growing stocks and species composition just before and for 5 years after official legal logging operations in 
two 1-ha established plots. Then, we compare the components of stand dynamics, including human disturbances (legal-cut, illegal-cut, and collateral deaths from tree felling) and natural processes (mortality, recruitment, and living tree growth).

\section{Materials and Methods}

\subsection{Study Site}

The study was conducted in Compartment 93 of South Zamaye Reserved Forests (RF) in Bago Yoma, a legendary forestry region in the lower central basin of Myanmar. The RF, composed of 119 compartments, includes 79,613 ha in area, and the study site, Compartment 93, is 740 ha in area, located at $17^{\circ} 50^{\prime} 48^{\prime \prime} \mathrm{N}, 96^{\circ} 7^{\prime} 19^{\prime \prime} \mathrm{E}$ (Figure 1). It has a typical tropical monsoon climate with two well-delineated seasons: a wet period from the end of May through October and a dry period from November through May. The mean annual rainfall is $3360 \mathrm{~mm}$, with an average humidity of $82.9 \%$, and the mean annual temperature is $26.7^{\circ} \mathrm{C}$ in Bago City [24], which is approximately $80 \mathrm{~km}$ southeast from the study site. The study site is not in an easily accessible area because it is situated upstream of the Zaungthu irrigation water reservoir in relatively undulating terrain. Tropical mixed deciduous forests, with the main characteristic species T. grandis, Xylia xylocarpa (Roxb.) Taub., Terminalia tomentosa Wight \& Arn., and Bambusa polymorpha Munro., were mainly found at the site. Locally, the forest type is natural teak-bearing deciduous forest.

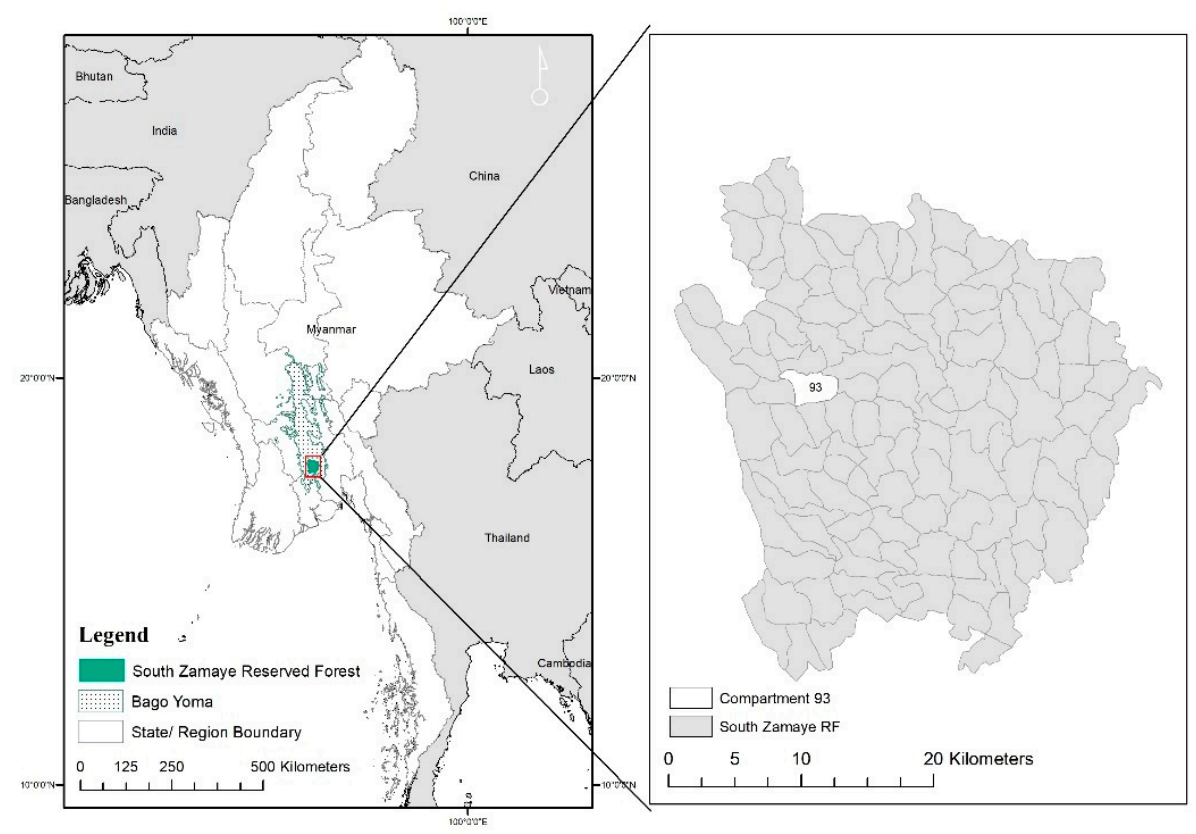

Figure 1. Location of the study site in Compartment 93, South Zamaye Reserved Forest, Bago Yoma, Myanmar.

Timber harvesting during 2012-2013 was the first instance of hardwood extraction from the study site after 1995. There were no accurate records available for timber extraction prior to 1995; however, existing old stumps indicated that timber was harvested at least twice prior to that year. Very old and decayed teak stumps were distinguishable by their texture, size $>73 \mathrm{~cm}$, and low heights $(\sim 0.2 \mathrm{~m})$, which met the criteria for felling teak [25]. Other higher hardwood stumps of various sizes were believed to indicate trees extracted in the 1990s prior to the construction of the Zaungthu Dam adjacent to the study site. 


\subsection{Timber Harvesting Operation}

For timber harvesting in Myanmar, tree species are classified into six commercial groups: T. grandis (teak) and non-teak hardwoods of Groups I-V. Group I species are the most important commercially because the trees' economic value decreases from Group I to IV, and Group V contains the lesser-used species. Whether a tree can be legally harvested is determined by the prescribed minimum diameter cut limit (MDCL), which varies with species and forest types in a geographical location. Timber harvesting plans for the extraction of $T$. grandis and non-teak hardwoods are usually determined separately. In the 2012-2013 fiscal year, T. grandis harvesting was not implemented in the study area. For hardwood species, the MDCL in the study site ranged from 58 to $78 \mathrm{~cm}$, while, for the major commercial species at the site-X. xylocarpa, Lagerstroemia speciose, and T. tomentosa-the MDCL was set at $68 \mathrm{~cm}$ [24]. A total of 1071 trees were marked by the Myanmar Forest Department to be extracted from Compartment 93 [22]. The government agency—the Myanmar Timber Enterprise-performed the logging operations, which mainly included tree felling, log stumping and skidding, logging road construction, and log transportation.

\subsection{Field Measeurments}

A 9-ha rectangular plot $(300 \mathrm{~m} \times 300 \mathrm{~m}$ ) with two inner 1-ha subplots, A and B (Figure 2), was established during December 2012. As a starting point for establishing the 9-ha plot, the south-east corner point of subplot A was subjectively located in an area with trees marked for felling, and the base and cross lines of each subplot were laid out in north-south and east-west directions, respectively, from that point [22]. When we located the corner point of subplot $A$, we attempted to find a location representative of a production stand in which the plot included some of the trees marked for harvesting, while avoiding inaccessible areas that were too steep and/or lacked commercial species [22]. Intensive tree measurements were taken in subplots $\mathrm{A}$ and $\mathrm{B}$. All the standing trees with a diameter at breast height $(\mathrm{DBH}) \geq 10 \mathrm{~cm}$ were individually numbered and tagged prior to the tree felling operation, and each tree's species was identified. Immediately after tree felling, residual trees damaged by the felled trees were assessed [22]. This investigation was completed in December 2012. In March 2013, when all the logging operations were completed, trees damaged as a result of the log skidding operation were traced and the number of trees removed owing to the road construction was determined. The area of the logging road was measured within the 9-ha plot.

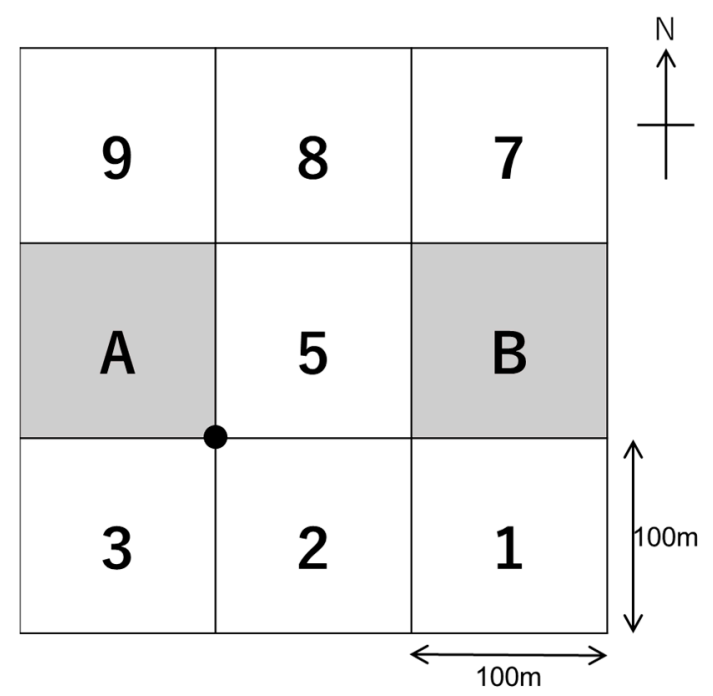

Figure 2. Layout of the nine 1-ha subplots in Compartment 93, South Zamaye Reserved Forest, Bago Yoma, Myanmar. The south-east corner of subplot A (black dot) was the starting point for establishing the plot. 
In December 2017, 5 years after the felling operations, all the trees with a $\mathrm{DBH} \geq 10 \mathrm{~cm}$ in subplots $A$ and B were re-measured, newly recruited trees that reached $10 \mathrm{~cm} \mathrm{DBH}$ were identified, and dead or missing trees were recorded.

\subsection{Sampling of Illegally Cut Trees}

At the site, we were able to distinguish illegal cutting from legal cutting based on the official hammer marks, and the sizes and heights of stumps in the field. In Myanmar, the legality of harvested trees can be checked using the precise official hammer-marking of the Forest Department and the timber extraction agency-Myanmar Timber Enterprise. For timber harvesting, exploitable trees that have attained the prescribed MDCL, for example, $\geq 58,68$, or $78 \mathrm{~cm} \mathrm{DBH}$, depending on the species at the site, are marked with two blazes, along with the selection felling number, at the lowest part of the bole height (below $\sim 45 \mathrm{~cm}$ ) and just above or below the 1.3-m bole height. Immediately after the selected tree is felled, a series of hammer marks, such as the selection felling number, number of marketable logs from felled trees, compartment code, and personal hammer of the officer in charge, are branded on the stump surface. Therefore, stumps without branded hammer marks indicate illegally cut trees. In addition, illegal stumps are usually higher and smaller in size than the MDCL.

\subsection{Data Analysis}

The stand-level attributes at pre-harvest (December 2012), immediate post-harvest, and 5-year post-harvest (December 2017) periods were examined for individual trees with a DBH $\geq 10 \mathrm{~cm}$. The causes of changes over time were classified into human disturbances and natural occurrences. Human disturbances include (i) official logging operations (tree felling, tree skidding, and road construction), including collateral tree death caused unintentionally during the official operations, and (ii) illegal cutting and collateral death caused unintentionally during tree felling. Natural occurrences include (iii) recruitment reaching a 10-cm DBH; (iv) natural deaths (mortality) of trees, both standing and fallen; and (v) the growth of living trees. We placed trees that we could not locate during the survey into the mortality category.

The annual mortality and recruitment rates were estimated using the following equation [26]:

$$
n_{1-2}=\frac{1}{t_{1-2}} \frac{n_{2}}{N_{1}} \times 100
$$

where $n_{1-2}$ represents the rate of mortality or recruitment in a percentage of trees per year; $t_{1-2}$ represents the time between measurements 1 and 2 in years; for mortality, $n_{2}$ represents the number of trees recorded during measurement 1 and dead at measurement 2; and, for recruitment, $n_{2}$ represents the number of trees newly reaching a $10 \mathrm{~cm} \mathrm{DBH}$ at measurement 2 and $N_{1}$ represents the number of trees in measurement 1 [26].

The DBH increment of individual trees with a $\mathrm{DBH} \geq 10 \mathrm{~cm}$ was calculated for trees surviving at measurement times 1 and 2. Recruited trees and five outliers with unrealistic data, which may have resulted from measurement errors, were excluded from the increment analysis.

The volume of a standing tree was calculated using the following equation developed for trees having $\geq 20-\mathrm{cm}$ DBH in Bago Yoma, Myanmar [27]:

$$
\mathrm{v}=b 0+b 1 \mathrm{D}+b 2 \mathrm{D}^{2}+b 3 \mathrm{D}^{3} \ldots \ldots \ldots b \mathrm{D}^{\mathrm{n}}
$$

where $\mathrm{v}$ represents the tree volume over bark $\left(\mathrm{m}^{3}\right)$, D represents the $\mathrm{DBH}(\mathrm{cm})$, and $b_{n}$ values represent parameters estimated for each species or species group. 


\section{Results}

\subsection{Stand Structure at Pre-Harvest}

Prior to the tree felling operation in December 2012, the density of trees with DBHs $\geq 10 \mathrm{~cm}$ in subplots A and B was 201 and 151 trees ha ${ }^{-1}$ (Table S1), with a basal area of 16.3 and $16.8 \mathrm{~m}^{2} \mathrm{ha}^{-1}$ (Table S2), and the volume of standing trees having a $\geq 20 \mathrm{~cm} \mathrm{DBH}$ was 111 and $131 \mathrm{~m}^{3} \mathrm{ha}^{-1}$, respectively (Table 1). The DBH distribution among trees showed an inverted J shape, typical of tropical natural forests [25]. The tree species richness was 42 and 40 species ha ${ }^{-1}$ in subplots $\mathrm{A}$ and $\mathrm{B}$, respectively, and there were 55 species in total for the 2-ha subplots. Among the 55 species, tropical mixed deciduous tree species of T. grandis, X. xylocarpa (Group I), and L. speciosa (Group III), representing 12.8\%, 9.38\%, and $9.38 \%$ of the tree density, respectively, were dominant. The species richness of bamboo was three in the 2-ha subplots, among which B. polymorpha was dominant, representing $74.8 \%$ of the 519 bamboo-clumps [25].

Table 1. Changes in the volume $\left(\mathrm{m}^{3} \mathrm{ha}^{-1}\right)$ of trees with a diameter at breast height (DBH) $\geq 20 \mathrm{~cm}$ for all and each species group.

\begin{tabular}{|c|c|c|c|c|c|c|c|c|c|}
\hline \multirow{3}{*}{ Years } & \multicolumn{3}{|c|}{ All Species } & \multicolumn{6}{|c|}{ Species Group (Mean of the Subplots A and B) } \\
\hline & \multirow{2}{*}{ Mean } & \multicolumn{2}{|c|}{ Subplot } & \multirow{2}{*}{ Teak } & \multirow{2}{*}{ Group1 } & \multirow{2}{*}{ Group2 } & \multirow{2}{*}{ Group3 } & \multirow{2}{*}{ Group4 } & \multirow{2}{*}{ Group5 } \\
\hline & & A & B & & & & & & \\
\hline Stock in 2012 before legal operations & 121 & 111 & 131 & 25.6 & 22.7 & 4.1 & 18.0 & 19.9 & 30.7 \\
\hline Legal disturbance in 2012 & -29.3 & -43.2 & -15.4 & 0.00 & -15.6 & 0.00 & -10.6 & -0.76 & -2.34 \\
\hline Legal cut & -25.5 & -35.6 & -15.4 & 0.00 & -14.9 & 0.0 & -9.8 & 0.00 & -0.81 \\
\hline Killed from legal-cut & -2.14 & -4.28 & 0.00 & 0.00 & -0.13 & 0.00 & -0.25 & -0.76 & -0.99 \\
\hline Killed from road construction & -1.65 & -3.31 & 0.00 & 0.00 & -0.56 & 0.00 & -0.56 & 0.00 & -0.54 \\
\hline Stock in 2012 after legal operations & 91.7 & 68.0 & 115 & 25.6 & 7.16 & 4.10 & 7.33 & 19.1 & 28.4 \\
\hline Illegal disturbance from 2012 to 2017 & -28.0 & -25.6 & -30.5 & -21.2 & -5.89 & -0.40 & 0.00 & -0.45 & -0.09 \\
\hline Illegal cut & -27.5 & -24.6 & -30.5 & -21.2 & -5.89 & -0.40 & 0.00 & 0.00 & 0.00 \\
\hline Killed from illegal-cut & -0.54 & -1.07 & 0.00 & 0.00 & 0.00 & 0.00 & 0.00 & -0.45 & -0.09 \\
\hline Natural changes from 2012 to 2017 & 1.45 & 2.58 & 0.33 & 0.63 & 0.53 & -0.38 & 0.29 & -0.80 & 1.19 \\
\hline Mortality & -7.94 & -5.64 & -10.23 & -0.31 & 0.00 & -0.90 & -0.69 & -2.73 & -3.31 \\
\hline Recruitment* & - & - & - & - & - & - & - & - & - \\
\hline Increment of living trees & 9.39 & 8.23 & 10.55 & 0.94 & 0.53 & 0.52 & 0.98 & 1.93 & 4.50 \\
\hline Stock in 2017 & 65.1 & 45.0 & 85.1 & 4.98 & 1.81 & 3.32 & 7.62 & 17.8 & 29.5 \\
\hline
\end{tabular}

* The volume of the recruited trees was not calculated because DBH of them was less than $20 \mathrm{~cm}$.

\subsection{Human Disturbance}

\subsubsection{Disturbances Caused by Official Logging Operations}

Within subplots A and B (2 ha), 5.0 trees ha ${ }^{-1}$ of commercial hardwood trees (tree volume of $25.5 \mathrm{~m}^{3} \mathrm{ha}^{-1}$ ) were harvested from species groups I, III, and V (Table 1 and Table S1, Figure 3). The number of residual trees that were killed collaterally by the official harvesting operation was 5.5 trees ha ${ }^{-1}$ (Table S1). The size of officially harvested trees (mean DBH $\pm \mathrm{SD}=83.9 \pm 20.5 \mathrm{~cm}$ ) was relatively larger than that of the collaterally killed trees (Figure 3). The log skidding operation was conducted using elephants, but no trees were observed to be damaged as a result of skidding. The logging roads constructed for forest access and as feeders used $84 \mathrm{~m} \mathrm{ha}^{-1}$ or $4.6 \%$ of the area [22]. During the logging road construction, 8.5 trees $\mathrm{ha}^{-1}$ were cleared or destroyed, but the sizes of these trees were relatively small (Table S1 and Figure 3). As a result, the total tree loss during the official timber harvesting operation was 19 trees ha $\mathrm{h}^{-1}\left(29.3 \mathrm{~m}^{3} \mathrm{ha}^{-1}\right)$, resulting in a reduction from 176 to 157 trees ha-1 (121 to $91.7 \mathrm{~m}^{3} \mathrm{ha}^{-1}$ ) (Table 1 and Table S1, and Figure 4). 


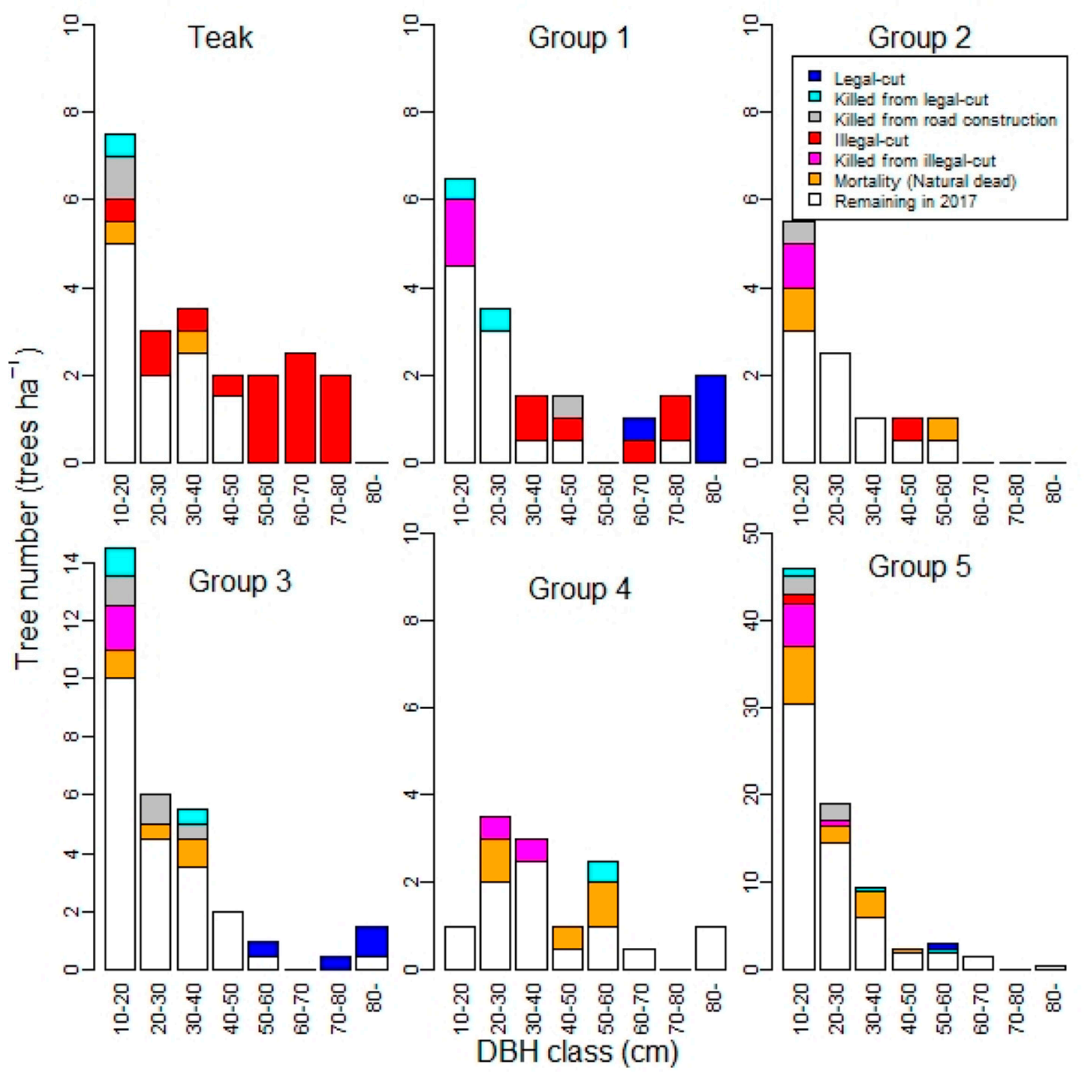

Figure 3. DBH distribution for each species group in Compartment 93, South Zamaye Reserved Forest, Bago Yoma, Myanmar, in 2012 and their classifications in 2017.

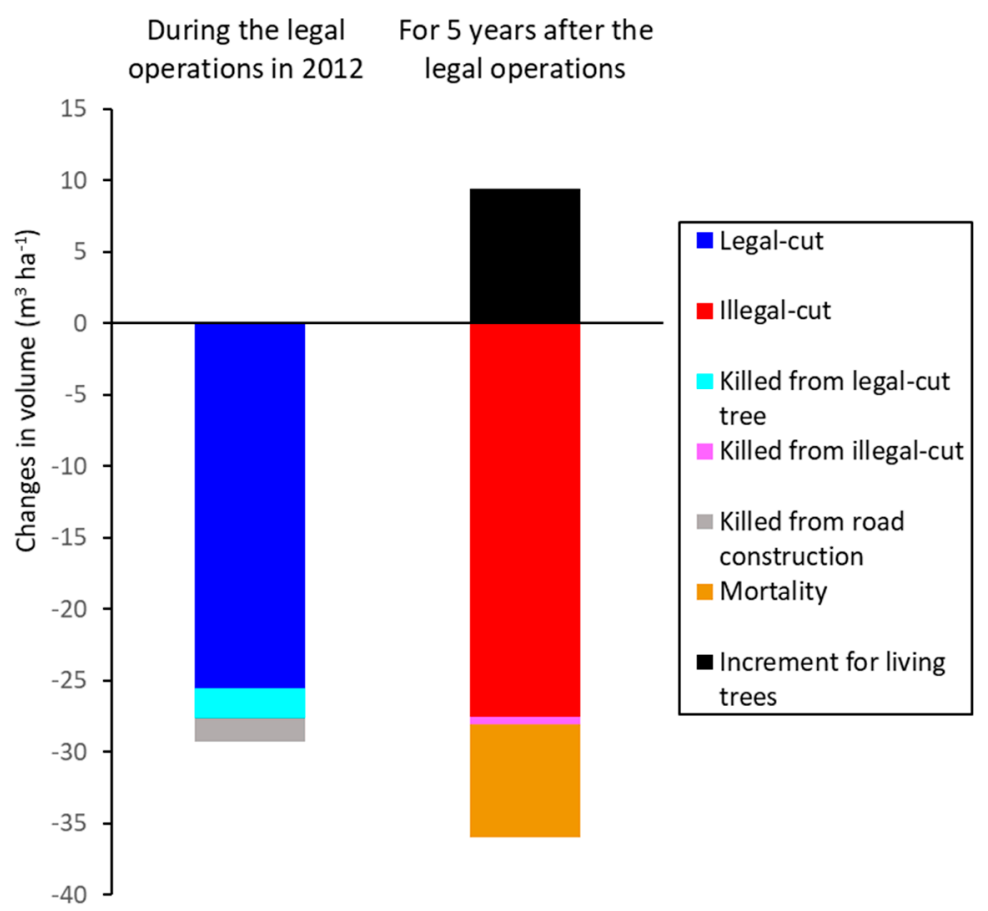

Figure 4. Changes in the volume $\left(\mathrm{m}^{3} \mathrm{ha}^{-1}\right)$ of trees with a $\mathrm{DBH} \geq 20 \mathrm{~cm}$ for each component of stand dynamics during the legal logging operations in 2012 and during the 5-year post-harvest period (2012-2017) in Compartment 93, South Zamaye Reserved Forest, Bago Yoma, Myanmar. 


\subsubsection{Disturbances from Illegal Logging}

We observed the trees that were illegally cut for 5 years after the official logging operations. The amount of illegal felling was 13.5 trees ha ${ }^{-1}\left(27.5 \mathrm{~m}^{3} \mathrm{ha}^{-1}\right)$ (Table 1 and Table S1). Illegally cut trees were mainly limited to relatively large trees, as well as smaller trees cut for use in saw pits [25] (Figure 3). It should also be noted that only the most economically valuable species- $T$. grandis (teak) and X. xylocarpa (Group I) - were mainly affected by illegal cutting (Figure 3). The number of trees that were collaterally killed as a result of felling illegally cut trees was 10.5 trees ha ${ }^{-1}\left(0.54 \mathrm{~m}^{3} \mathrm{ha}^{-1}\right)$, but the sizes of these killed trees were relatively small (Table 1 and Table S1, and Figure 3). Overall, the number of illegally cut trees and the subsequent residual trees killed during felling amounted to 24.0 trees $\mathrm{ha}^{-1}\left(28.0 \mathrm{~m}^{3} \mathrm{ha}^{-1}\right)$ being lost over the 5-year post-harvest period (Table 1 and Table S1).

\subsection{Natural Occurrences}

\subsubsection{Mortality, Recruitment, and Living Tree Growth}

The mortality was 19.5 trees ha ${ }^{-1}\left(7.94 \mathrm{~m}^{3} \mathrm{ha}^{-1}\right)$ for the 5 -year post-harvest period (Table 1 and Table S1), and on an annual basis, the mortality rate was $2.5 \%$. The mortality rate was greater for relatively smaller-sized trees and for species groups 2-5 (Figure 3). The recruitment was 24.5 trees ha ${ }^{-1}$ for the 5-year post-harvest period (Table 1 and Table S1), and the annual recruitment rate was $3.1 \%$. For the recruited trees, the DBH was relatively small, being between 10 to $20 \mathrm{~cm}$, and thus, the basal area was also relatively small $\left(0.3 \mathrm{~m}^{2}\right)$ (Table S2). The volume was not calculated since volume equations are only applicable to trees with a $\mathrm{DBH} \geq 20 \mathrm{~cm}$. Among species groups, the recruitment was particularly small between 0 to 1.5 trees ha $^{-1}$ for Teak, Group 1, and Group 2 (Table S1).

The amount of mortality and increment of living trees were relatively similar for all trees (7.94 and $9.39 \mathrm{~m}^{3} \mathrm{ha}^{-1}$ ), as well as for each species group (Table 1 and Table S2). As a result, the total change caused by natural occurrences, including mortality, recruitment, and living tree growth, was relatively small for the 5-year post-harvest period $\left(1.45 \mathrm{~m}^{3} \mathrm{ha}^{-1}\right)$ (Table 1, Tables S1 and S2).

\subsubsection{Diameter Growth Rates}

For all the species, the mean $( \pm \mathrm{SD})$ of the annual DBH increment rate over the 5-year post-harvest period was $0.48 \pm 0.30 \mathrm{~cm}_{\text {year }}^{-1}$, which is significantly larger than the standard growth rate of $0.32 \mathrm{~cm}$ year $^{-1}$ that has been traditionally used to calculate the sustained yield for the 30-year cutting cycle (t-test, $p<0.05)$. For each of the species groups, the means for Teak $(0.54 \mathrm{~cm})$, Group $1(0.69 \mathrm{~cm})$, Group $4(0.55 \mathrm{~cm})$, and Group $5(0.46)$ were significantly larger than $0.32 \mathrm{~cm}$, but there was no significant difference for Group $2(0.46 \mathrm{~cm})$ and Group $3(0.39 \mathrm{~cm})$ (Table S3 and Figure S1).

\subsubsection{Changes Over the 5-Year Post-Harvest Period}

There were substantial decreasing trends over the 5-year post-harvest period, with reductions of $46 \%$ (121 to $65.1 \mathrm{~m}^{3} \mathrm{ha}^{-1}$ ) (Figure 5 and Table 1). Among species groups, the large reductions from legal operations in 2012 were only found for Group 1 and 3, while a large reduction after legal operations only occurred for Teak and Group 1 (Figure 5 and Table 1). Before the legal operations, Teak and Group 1 shared $40 \%\left(48.3 \mathrm{~m}^{3} \mathrm{ha}^{-1}\right)$ of the total volume $\left(121 \mathrm{~m}^{3} \mathrm{ha}^{-1}\right)$, but after the 5 -year post-harvest period, the share decreased to $10 \%$, while the other four species groups represented $90 \%$ (Figure 5 and Table 1 ). 


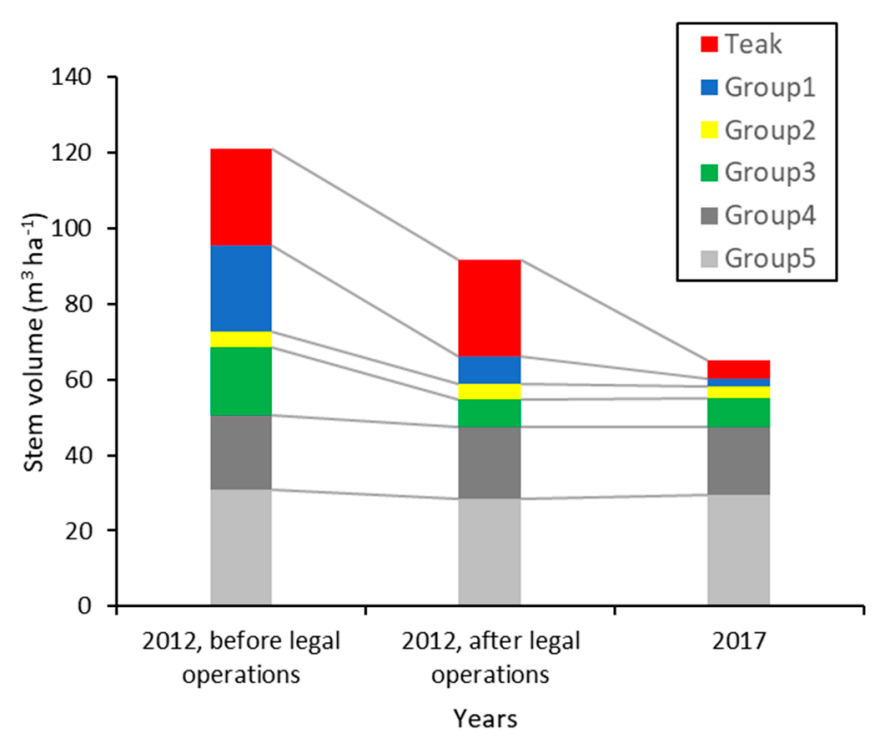

Figure 5. The volume of trees with a $\mathrm{DBH} \geq 20 \mathrm{~cm}$ for each species group before and after the legal operations in 2012 and in 2017 in Compartment 93, South Zamaye Reserved Forest, Bago Yoma, Myanmar.

\section{Discussion}

\subsection{Human Disturbances}

The logging intensity is a critical factor that determines residual tree damage, soil disturbance [28], and biodiversity loss [29] during tropical selective logging. The intensity of official logging in this study ( 5 trees ha ${ }^{-1}$ and $25.5 \mathrm{~m}^{3} \mathrm{ha}^{-1}$ ) is relatively low compared with the maximum ranges reported in the tropics, such as 20 trees ha ${ }^{-1}$ [30], $70 \mathrm{~m}^{3} \mathrm{ha}^{-1}$ [28], and $200 \mathrm{~m}^{3} \mathrm{ha}^{-1}$ [29]. Sist et al. (1998) [31] suggested that the felling intensity of reduced-impact logging must be limited to a maximum of 8 trees ha ${ }^{-1}$ to reduce logging damage by $50 \%$ in comparison with conventional logging. Therefore, the intensity of official logging in this case study may not be the main reason for forest degradation. However, the amount of illegal logging was substantial, and its volume $\left(27.5 \mathrm{~m}^{3} \mathrm{ha}^{-1}\right)$ over the 5 -year post-harvest period was similar to that of official logging. When we considered the total of human-induced disturbances, which included official road construction and collateral death caused by felling legally and illegally cut trees, the amounts of killed trees were similar between legal and illegal disturbances ( 29.3 and $28.0 \mathrm{~m}^{3} \mathrm{ha}^{-1}$, respectively). The volume affected by illegal disturbances was considerably greater than the 5-year volume increase $\left(1.45 \mathrm{~m}^{3} \mathrm{ha}^{-1}\right)$ resulting from natural occurrences (mortality, recruitment, and living tree growth). Using data from only 5-year measurements, we could not determine whether stocking would recover to the pre-harvest level for the 30-year cutting cycle, but it was clear that illegal disturbances are the main cause of the large reduction in stocking after official logging (Figure 4).

Our field measurements confirm that illegal logging occurred after the official logging. Illegal logging has a large impact not only on stocking, but also on the species composition. The illegal logging targeted two of the most commercially important species-T. grandis and Group 1 (X. xylocarpa). The mean DBH $( \pm S D)$ of illegally cut $T$. grandis and X. xylocarpa was $58.1 \pm 16.9$ and $49.1 \pm 18.2$, respectively, which are lower than the MDCLs (63 cm for T. grandis and $68 \mathrm{~cm}$ for X. xylocarpa) [32]. Even though official timber harvesting of $T$. grandis was not implemented at this study site, all the trees larger than the MDCL $(63 \mathrm{~cm})$, i.e., Class I, and all the trees of Class II, which are between $53 \mathrm{~cm}$ and the MDCL $(63 \mathrm{~cm})$, have been cut illegally (Figure 3$)$. Therefore, T. grandis will not be available in the next cutting cycle. A similar situation was found for X. xylocarpa (Group I), most of which are in Class I and II, and were illegally cut (Figure 3). 


\subsection{Natural Occurrences: Mortality, Recruitment, and Living Tree Growth}

Although mortality and recruitment may vary between species and diameter classes, the mean mortality rate $(2.5 \%)$ in the present study was similar to, or well within the range of, reported values from tropical rain forests in the Amazon and Southeast Asia. Generally, the annual mortality rates range between $1 \%$ and $2 \%$ per year in non-logged natural tropical forests [33], but the values are often higher for recently logged forests and tend to decrease over the years after timber harvesting. For example, Silva et al. (1995) [34] reported mortality rates of 2.6\%, 2.4\%, and 2.2\% per year in Tapajós National Forest, 5, 6, and 11 years after the harvest, respectively. The highest mortality rates are observed during the first 2-year post-harvest period [26,35], and mortality rates stabilize later, for between 7-year and 11-year [36], between 5-year and 10-year [26], or after 15-year [6] post-harvest periods.

The mean recruitment rate $(3.1 \%)$ in the present study was greater than the $2.33 \% \pm 0.13 \%(n=32)$ and $1.75 \% \pm 0.66 \%(n=9)$ values reported for mature rain forests in the Amazon Basin [37] and Southeast Asia [38], respectively. The increasing intensity of logging results in more recruitment [13]. Therefore, the large recruitment in this study may result from disturbances caused by both legal and illegal logging. However, it should be noted that there were no and only 1.5 trees ha ${ }^{-1}$ requirements over 5 years for the first- and second-grade species T. grandis and X. xylocarpa, respectively, which were largely reduced by illegal and/or legal disturbance (Table S1). In contrast, more requirements were found in the three-grade species group (Table S1). Therefore, it may be difficult to harvest high-grade timber species in the future, even though our results were only obtained over a 5-year period.

The net changes in stocking from natural occurrences (natural mortality, recruitment, and increment of living trees) over 5 years were small, since the gain from the increment was similar to the loss from the morality for all species, while the gain from recruitment was relatively small. This indicates that the changes due to natural occurrences are much smaller than those from legal and illegal human disturbances (Figure 4).

\subsection{Diameter Increment}

The diameter growth rate is an important parameter for calculating the AAC, and $0.32 \mathrm{~cm}_{\text {year }}^{-1}$ is currently adopted for the 30-year cutting cycle of the Myanmar Selection System. AAC is estimated based on the number of commercial trees in Class I, which represents the currently harvestable DBH class, being equal or more than the MDCL, and Class II, which can reach the MDCL within a 30-year cutting cycle. The DBH range of Class II is from MDCL to MDCL minus $10 \mathrm{~cm}$, which is determined by the average growth rate multiplied by the cutting cycle $\left(0.32 \mathrm{~cm} \mathrm{year}^{-1} \times 30\right.$ years $\left.=9.6 \mathrm{~cm}\right)$. For Teak with an MDCL $=63 \mathrm{~cm}$, Class I is $>63 \mathrm{~cm}$ and Class II is $53-63 \mathrm{~cm}$. Therefore, if the currently adopted growth rate $\left(0.32 \mathrm{~cm}_{\text {year }}{ }^{-1}\right)$ overestimates (or underestimates) the real growth, the Class II range and AAC are overestimated (or underestimated). Because the currently adopted value $\left(0.32 \mathrm{~cm} \mathrm{year}^{-1}\right)$ is significantly smaller than our finding $\left(0.48 \mathrm{~cm}_{\text {year }}{ }^{-1}\right)$, the current AAC based on a growth rate of $0.32 \mathrm{~cm}$ year $^{-1}$ may not be an overestimation, but an underestimation.

However, growth rates in logged forests are highest during the early post-logging period owing to the increases in open space and sunlight available to residual trees, and growth rates exhibit decreasing trends over time after logging. The highest growth rates occur at 5 years after harvest and gradually decrease to the level of the unlogged control area at 11-years post-logging in a Brazilian tropical forest [7] and 16-years post-logging in a Ghanaian high forest [39]. Therefore, the growth rate of $0.48 \mathrm{~cm}_{\text {year }}{ }^{-1}$ from 5-year post-harvest measurements is likely overestimated as an average for the 30 -year post-harvest period, and thus, the currently adopted value $\left(0.32 \mathrm{~cm}\right.$ year $\left.{ }^{-1}\right)$ may not represent an underestimation for the 30-year cutting cycle [22].

\section{Conclusions}

There were similarities in stand dynamic components, such as disturbance from legal logging operations, natural mortality, recruitment, and tree growth rates, between previous studies of tropical 
forests and this study, which was based at a traditional forestry site in Myanmar. However, the magnitude (volume) of illegal logging is similar to that of legal logging and considerably larger than changes caused by other components of stand dynamics. Illegal logging also causes dramatically decreasing numbers of large-size commercial trees, particularly $T$. grandis and X. xylocarpa. Therefore, illegal logging following legal logging is the most critical factor causing forest degradation, at least in terms of the provisioning services of the selectively logged production forest ecosystem. It should be cautioned that this study is based on data from 5-year measurements, so longer term monitoring is essential for evaluating the sustainability of selectively logged production forests over a 30-year cutting cycle.

Supplementary Materials: The following are available online at http://www.mdpi.com/1999-4907/11/2/195/s1, Figure S1: Annual DBH increment for each species group, Table S1: Changes in the density (trees ha ${ }^{-1}$ ) of trees with DBH $\geq 10 \mathrm{~cm}$ for all and each species group., Table S2: Changes in basal area $\left(\mathrm{m}^{2} \mathrm{ha}^{-1}\right)$ of trees with DBH 10 $\geq \mathrm{cm}$ for all and each species group, Table S3: Annual DBH increment $\left(\mathrm{cm}\right.$ year $\left.{ }^{-1}\right)$ for species group.

Author Contributions: T.C.K., N.M., and T.O. performed the analysis and wrote the manuscript. All authors have read and agreed to the published version of the manuscript.

Funding: This study was funded by JSPS KAKENHI (grant number JP19H04339) and a Grant for Environmental Research Projects from the Sumitomo Foundation.

Acknowledgments: We thank the Forest Department of Myanmar, particularly the Bago Township Forest Department, for their support and arranging our field work. We thank Lesley Benyon, from Edanz Group (www.edanzediting.com/ac), for editing a draft of this manuscript. The author was financially supported by the Japan Human Resource Development Scholarship.

Conflicts of Interest: The authors declare no conflict of interest.

\section{References}

1. Keenan, R.J.; Reams, G.A.; Achard, F.; de Freitas, J.V.; Grainger, A.; Lindquist, E. Dynamics of Global Forest Area: Results from the FAO Global Forest Resources Assessment 2015. For. Ecol. Manage. 2015, 352, 9-20. [CrossRef]

2. Blaser, J.; Sarre, A.; Poore, D.; Johnson, S. Status of Tropical Forest Management 2011; ITTO Technical Series No 38; International Tropical Timber Organization: Yokohama, Japan, 2011.

3. Chheng, K.; Mizoue, N.; Khorn, S.; Kao, D.; Sasaki, N. Tree-Based Approach to Evaluate Size Dependence of Residual Tree Damage Caused by Selective Logging: Case Study in Tropical Semi-Evergreen Forests of Cambodia. For. Ecol. Manag. 2015, 356, 285-292. [CrossRef]

4. Poudyal, B.H.; Maraseni, T.; Cockfield, G. Evolutionary dynamics of selective logging in the tropics: A systematic review of impact studies and their effectiveness in sustainable forest management. For. Ecol. Manag. 2018, 430, 166-175. [CrossRef]

5. Cole, L.E.S.; Bhagwat, S.A.; Willis, K.J. Recovery and resilience of tropical forests after disturbance. Nat. Commun. 2014, 5, 3906. [CrossRef] [PubMed]

6. De Avila, A.L.; Schwartz, G.; Ruschel, A.R.; Lopes, J.D.C.; Silva, J.N.M.; De Carvalho, J.O.P.; Dormann, C.F.; Mazzei, L.; Soares, M.H.M.; Bauhus, J. Recruitment, growth and recovery of commercial tree species over 30 years following logging and thinning in a tropical rain forest. For. Ecol. Manag. 2017, 385, 225-235. [CrossRef]

7. Dionisio, L.F.S.; Schwartz, G.; Lopes, J.D.C.; Oliveira, F.D.A. Growth, mortality, and recruitment of tree species in an Amazonian rainforest over 13 years of reduced impact logging. For. Ecol. Manag. 2018, 430, 150-156. [CrossRef]

8. Rozendaal, D.M.A.; Soliz-Gamboa, C.C.; Zuidema, P.A. Timber Yield Projections for Tropical Tree Species: The Influence of Fast Juvenile Growth on Timber Volume Recovery. For. Ecol. Manag. 2010, 259, 2292-2300. [CrossRef]

9. Peart, D.; Leighton, M.; Cannon, C. Tree Species Diversity in Commercially Logged Bornean Rainforest. Science 1998, 281, 1366-1368. [CrossRef]

10. Yosi, C.K.; Keenan, R.J.; Fox, J.C. Forest Dynamics after Selective Timber Harvesting in Papua New Guinea. For. Ecol. Manag. 2011, 262, 895-905. [CrossRef] 
11. Yamada, T.; Hosaka, T.; Okuda, T.; Kassim, A.R. Effects of 50years of Selective Logging on Demography of Trees in a Malaysian Lowland Forest. For. Ecol. Manag. 2013, 310, 531-538. [CrossRef]

12. Shima, K.; Yamada, T.; Okuda, T.; Fletcher, C.; Kassim, A.R. Dynamics of Tree Species Diversity in Unlogged and Selectively Logged Malaysian Forests. Sci. Rep. 2018, 8, 1-8. [CrossRef]

13. Higuchi, F.; Amaral, M.; Lima, A.; Higuchi, N.; Dos Santos, J. Dynamics of Tropical Forest Twenty-Five Years after Experimental Logging in Central Amazon Mature Forest. Forests 2019, 10, 89. [CrossRef]

14. Win, Z.C.; Mizoue, N.; Ota, T.; Wang, G.; Innes, J.L.; Kajisa, T.; Yoshida, S. Spatial and Temporal Patterns of Illegal Logging in Selectively Logged Production Forest: A Case Study in Yedashe, Myanmar. J. For. Plan. 2018, 23, 15-25. [CrossRef]

15. Kao, D.; Mizoue, N.; Top, N.; Kajisa, T.; Yoshida, S. Stand Dynamics of Tropical Seasonal Evergreen Forest in Central Cambodia. J. For. Plan. 2010, 16, 27-32.

16. Forest Department. Management of Teak Forests in Myanmar; Forest Department: Bago, Myanmar, 2000.

17. Wilson, S.M.; Yoshida, T.; Puettmann, K.J.; Amente, G.; Nocentini, S.; Donoso, P.J.; Putz, F.E.; Drössler, L.; Harvey, B.D.; Knoke, T.; et al. Silvicultural Alternatives to Conventional Even-Aged Forest Management-What Limits Global Adoption? For. Ecosyst. 2015, 2. [CrossRef]

18. Dah, S.E. Teak and Forest Management in Myanmar; ITTO Trop for Update 14/1; International Tropical Timber Organization: Yokohama, Japan, 2004; pp. 12-13.

19. Mon, M.S.; Mizoue, N.; Htun, N.Z.; Kajisa, T.; Yoshida, S. Factors Affecting Deforestation and Forest Degradation in Selectively Logged Production Forest: A Case Study in Myanmar. For. Ecol. Manag. 2012, 267, 190-198. [CrossRef]

20. Mon, M.S.; Kajisa, T.; Mizoue, N.; Yoshida, S. Monitoring Deforestation and Forest Degradation in the Bago Mountain Area, Myanmar Using FCD Mapper. Jpn. Soc. For. Plan. 2010, 15, 63-72.

21. Win, Z.C.; Mizoue, N.; Ota, T.; Kajisa, T.; Yoshida, S.; Oo, T.N.; Ma, H. Evaluating the Condition of Selectively Logged Production Forests in Myanmar: An Analysis Using Large-Scale Forest Inventory Data for Yedashe Township. J. For. Plan. 2018, 23, 1-8. [CrossRef]

22. Khai, T.C.; Mizoue, N.; Kajisa, T.; Ota, T.; Yoshida, S. Effects of Directional Felling, Elephant Skidding and Road Construction on Damage to Residual Trees and Soil in Myanmar Selection System. Int. For. Rev. 2016, 18, 296-305. [CrossRef]

23. Kyaw, N.N. The Effect of Rainfall on the Radial Growth and Long-Term Growth Patterns of Teak (Tectona Grandis Linn.f.) in Natural Forests of Myanmar; FRI Reseasrch Paper No. 10; Forest Research Institute: Yezin, Myanmar, 2003; pp. 296-313.

24. Forest Department. Bago District Forest Managment Plan (2006-2015); Forest Department: Bago, Myanmar, 2010.

25. Khai, T.C.; Mizoue, N.; Kajisa, T.; Ota, T.; Yoshida, S. Stand Structure, Composition and Illegal Logging in Selectively Logged Production Forests of Myanmar: Comparison of Two Compartments Subject to Different Cutting Frequency. Glob. Ecol. Conserv. 2016, 7, 132-140. [CrossRef]

26. Sist, P.; Nguyen-Thé, N. Logging Damage and the Subsequent Dynamics of a Dipterocarp Forest in East Kalimantan (1990-1996). For. Ecol. Manag. 2002. [CrossRef]

27. Leech, J.W.; Myint, A.K.; Kyaw, S.; Lynn, H. Tree Volume Equations for Myanmar; Prachachon Col., Ltd.: Bangkok, Thailand, 1986.

28. Pereira, R.; Zweede, J.; Asner, G.P.; Keller, M. Forest Canopy Damage and Recovery in Reduced-Impact and Conventional Selective Logging in Eastern Para, Brazil. For. Ecol. Manag. 2002, 168, 77-89. [CrossRef]

29. Burivalova, Z.; Şekercioğlu, Ç.H.; Koh, L.P. Thresholds of Logging Intensity to Maintain Tropical Forest Biodiversity. Curr. Biol. 2014, 24, 1893-1898. [CrossRef] [PubMed]

30. Picard, N.; Gourlet-Fleury, S.; Forni, É. Estimating Damage from Selective Logging and Implications for Tropical Forest Management. Can. J. For. Res. 2012, 42, 605-613. [CrossRef]

31. Sist, P.; Nolan, T.; Bertault, J.G.; Dykstra, D. Harvesting Intensity versus Sustainability in Indonesia. For. Ecol. Manag. 1998, 108, 251-260. [CrossRef]

32. Forest Department. Bago District Forest Management Plan (2016-2025); Forest Department: Bago, Myanmar, 2016.

33. Swaine, M.D.; Lieberman, D.; Putz, F.E. The Dynamics of Tree Populations in Tropical Forest: A Review. J. Trop. Ecol. 1987, 3, 359-366. [CrossRef] 
34. Silva, J.; De Carvalho, J.; Lopes, J.C.; De Almeida, B.; Costa, D.; De Oliveira, L.; Vanclay, J.; Skovsgaard, J. Growth and yield of a tropical rain forest in the Brazilian Amazon 13 years after logging. For. Ecol. Manag. 1995, 71, 267-274. [CrossRef]

35. Shenkin, A.; Bolker, B.; Peña-Claros, M.; Licona, J.C.; Putz, F.E. Fates of Trees Damaged by Logging in Amazonian Bolivia. For. Ecol. Manag. 2015, 357, 50-59. [CrossRef]

36. Dionisio, L.F.S.; Schwartz, G.; Mazzei, L.; Lopes, J.D.C.; Dos Santos, G.G.A.; Oliveira, F.D.A. Mortality of stocking commercial trees after reduced impact logging in eastern Amazonia. For. Ecol. Manag. 2017, 401, 1-7. [CrossRef]

37. Phillips, O.L.; Baker, T.R.; Arroyo, L.; Higuchi, N.; Killeen, T.J.; Laurance, W.F.; Lewis, S.L.; Lloyd, J.; Malhi, Y.; Monteagudo, A.; et al. Pattern and Process in Amazon Tree Turnover, 1976-2001. Philos. Trans. R. Soc. B Biol. Sci. 2004, 359, 381-407. [CrossRef]

38. Phillips, O.L.; Gentry, A.H. Increasing Turnover in Tropical Forests. Science 1994, 263, 954-958. [CrossRef] [PubMed]

39. Hawthorne, W.D.; Sheil, D.; Agyeman, V.K.; Abu Juam, M.; Marshall, C.A.M. Logging Scars in Ghanaian High Forest: Towards Improved Models for Sustainable Production. For. Ecol. Manag. 2012, 271, 27-36. [CrossRef]

(C) 2020 by the authors. Licensee MDPI, Basel, Switzerland. This article is an open access article distributed under the terms and conditions of the Creative Commons Attribution (CC BY) license (http://creativecommons.org/licenses/by/4.0/). 